\title{
INVESTIGATING THE RELATIONSHIP BETWEEN THE FOREIGN LANGUAGE READING ANXIETY AND READING PROFICIENCY: A CASE STUDY OF PREPARATORY YEAR STUDENTS AT THE UNIVERSITY OF JEDDAH
}

\section{INVESTIGANDO A RELAÇÃO ENTRE A ANSIEDADE DE LEITURA E A PROFICIÊNCIA DE LEITURA DA LÍNGUA ESTRANGEIRA: UM ESTUDO DE CASO DE ALUNOS DE ANO PREPARATÓRIO DA UNIVERSIDADE DE JEDDA}

\section{INVESTIGANDO LA RELACIÓN ENTRE LA ANSIEDAD LECTORA Y LA COMPETENCIA LECTORA EN IDIOMAS EXTRANJEROS: UN ESTUDIO DE CASO DE ESTUDIANTES DEL AÑO PREPARATORIO EN LA UNIVERSIDAD DE JEDDAH}

\begin{abstract}
This study is an in-depth analysis on the association between the anxiety experienced known as Foreign Language Reading Anxiety (FLRA) and the proficiency in reading exhibited by the preparatory year students. The Saudi learners from the science and arts stream and the gender were also considered as the moderator variables for this study. A mixed group of 84 students from both the genders of the preparatory year studying English at the Institution of Languages from the University of Jeddah were considered as the variables for this research. The participants were measured on as 20-item Likert-style Foreign Language Reading Anxiety Scale and examined by undergoing a 20-item proficiency test in reading a comprehension and a demographic questionnaire. The data was analyzed by applying The Pearson product moment correlation, t-Test, and descriptive analysis. The results indicated that the anxiety level while reading had varied values from moderate to high most of the respondents in the test were found to be in the moderate anxiety group. In addition, a notable negative relationship was found to be existing between the FLRA and the reading proficiency. The association existing between the foreign language reading anxiety and the group field was identified in this study. Analyzing the concept considering the gender, the female students were identified to experience more anxiety compared to the male students involved in the study. The findings of this study are advantageous to the language teachers and the curriculum planners too. It enables them to decrease the deteriorating and weakening factors in the classroom and thereby improve the reading ability of the language learners'. Reducing the reading anxiety amongst the learners can be achieved by exposing the language learners to understandable reading texts and familiarize them with cultural texts. This in turn develops the learners' self-confidence and motivates them to be better readers.
\end{abstract}

\footnotetext{
${ }^{1}$ University of Jeddah, Saudi Arabia.
} 
Keywords: English as a Foreign language, Reading anxiety, Gender, Reading proficiency, Level of reading anxiety.

Resumo: Este estudo é uma análise aprofundada sobre a associação entre a ansiedade vivenciada conhecida como Ansiedade pela Leitura em Língua Estrangeira (FLRA) e a proficiência em leitura exibida pelos alunos do ano preparatório. Os alunos sauditas da corrente de ciências e artes e o gênero também foram considerados as variáveis moderadoras deste estudo. Um grupo misto de 84 alunos de ambos os sexos do ano preparatório que estudam inglês no Instituto de Línguas da Universidade de Jeddah foram considerados como variáveis para esta pesquisa. Os participantes foram medidos em uma Escala de Ansiedade de Leitura de Língua Estrangeira de estilo Likert de 20 itens e examinados por meio de um teste de proficiência de 20 itens na leitura de um questionário de compreensão e demográfico. Os dados foram analisados aplicando a correlação de momento do produto de Pearson, teste t e análise descritiva. Os resultados indicaram que o nível de ansiedade durante a leitura variou de moderado a alto, a maioria dos respondentes do teste encontrava-se no grupo de ansiedade moderada. Além disso, foi encontrada uma relação negativa notável entre a FLRA e a proficiência de leitura. A associação existente entre a ansiedade de leitura em língua estrangeira e o campo do grupo foi identificada neste estudo. Analisando o conceito considerando o gênero, identificou-se que as alunas vivenciam mais ansiedade em relação aos alunos do sexo masculino envolvidos no estudo. As conclusões deste estudo são vantajosas para os professores de línguas e também para os planejadores de currículo. Permite-lhes diminuir os fatores de deterioração e enfraquecimento na sala de aula e, assim, melhorar a capacidade de leitura dos alunos de línguas. A redução da ansiedade da leitura entre os alunos pode ser alcançada expondo os alunos de línguas a textos de leitura compreensíveis e familiarizando-os com textos culturais. Isso, por sua vez, desenvolve a autoconfiança dos alunos e os motiva a serem leitores melhores.

Palavras-chave: Inglês como Língua Estrangeira, Ansiedade de leitura, Gênero, Proficiência em leitura, Nível de ansiedade de leitura.

Resumen: Este estudio es un análisis en profundidad de la asociación entre la ansiedad experimentada conocida como Ansiedad de Lectura en Lengua Extranjera (FLRA) y la competencia en lectura exhibida por los estudiantes del año preparatorio. Los estudiantes sauditas de la corriente de ciencias y artes y el género también se consideraron como variables moderadoras de este estudio. Un grupo mixto de 84 estudiantes de ambos géneros del año preparatorio que estudian inglés en la Institución de Idiomas de la Universidad de Jeddah fueron considerados como las variables para esta investigación. Los participantes se midieron con una Escala de Ansiedad Lectora de Lengua Extranjera de estilo Likert de 20 ítems y se examinaron mediante una prueba de competencia de 20 ítems en lectura, comprensión y un cuestionario demográfico. Los datos se analizaron aplicando la correlación de momento del producto de Pearson, la prueba t y el análisis descriptivo. Los resultados indicaron que el nivel de ansiedad al leer tenía valores variados de moderado a alto, la mayoría de los encuestados en la prueba se encontraban en el grupo de ansiedad moderada. Además, se encontró que existía una relación negativa notable entre el FLRA y la competencia lectora. En este estudio se identificó la asociación existente entre la ansiedad lectora en lengua extranjera y el campo grupal. Analizando el concepto considerando el género, se identificó que las alumnas experimentaron más ansiedad en comparación con los alumnos varones involucrados en el estudio. Los resultados de este estudio también son ventajosos para los profesores de idiomas y para los planificadores del plan de estudios. Les permite disminuir los factores de deterioro y debilitamiento en el aula y, por lo tanto, mejorar la capacidad de lectura de los estudiantes de idiomas. La reducción de la ansiedad por la lectura entre los alumnos se puede lograr exponiendo a los alumnos de idiomas a textos de lectura comprensibles y familiarizándolos 
con textos culturales. Esto, a su vez, desarrolla la confianza en sí mismos de los alumnos y los motiva a ser mejores lectores.

Palabras clave: inglés como lengua extranjera, ansiedad lectora, género, competencia lectora, nivel de ansiedad lectora.

\section{INTRODUCTION}

The influencing in the reading process has been an important subject of study during the last two decades. Among the numerous factors that add to influencing the reader's skill, a major impact is made by Foreign Language Anxiety (FLA). Reading has become a basic requirement and an inevitable part for every individual. The capability to read fluently is at present being an indispensable necessity for the learners of different academic levels and for equipping oneself with a good career opportunity. (Rajab, Wan Zakaria, Abdul Rahman, Hosni, Hassani 2012). The skill of reading is identified as one of the important skills to be equipped by many L2 language learners and in particular by the university students undergoing courses and studies related to EFL. Oxford 1999 defined foreign language anxiety as "the fear or apprehension occurring when a learner is expected to perform the second of foreign language (59)". Human beings can be easily influenced by affective variables considering the fact that they can be easily influenced by emotions. (Mohammadpur \& Ghafournia, 2015). Horwitz, Horwitz, Cope (1986) identified that anxiety caused by reading a foreign language is experienced due to the conflicting ideology between the mature thoughts of the foreign language student and the immature proficiency in their unfamiliar language. It is further noted in their studies that foreign language anxiety as a unique and a multifaceted phenomenon.

Previous researches in this field of study have laid emphasis to the broader concept of FLA. However the recent studies give importance and focus on associating it with specific skills. For example, Cheng (2002) conducted a study on the writing skills whereas Saito, Horwitz \& Garza (1999) linked FLA with reading skills. This study, aims to bring to limelight and provide insights about the relationship between FLA and reading skill among the preparatory learners of English language at the University of Jeddah. The researchers in this paper present their findings on the interdependency and the correlation between the FLA and reading proficiency as well as other variables i.e. gender and age.

\section{LITERATURE REVIEW}

Academic scholars in the field of FLA are at present conducting researches and concentrating on the association between FLA and specific language learning skills. The anxious feel or the disappointment arising within an individual when the reader fails to understand and interpret a text in L2 efficiently and effectively is called as Foreign language reading anxiety (FLRA) (Capan \& Karaca 2013; Zhou 2017).

According to Horwitzet al. (1986), FLRA “... is a distinct complex of self-perceptions, beliefs, feelings and behaviors related to classroom language learning arising from the uniqueness of the language learning process" (p. 31). The meaning and explanation of FLRA is discussed in literature as "self-perceptions, beliefs, feelings and behaviors" (Young, 1998). 
The reading anxiety is found to be maximum and increasing in foreign language contexts. The readers must possess specific cognitive skills like attention, perception, memory and comprehension (Sellers, 2000). Among the people who belong to the reading strata of the society, it is believed that a person who reads is supposed to be devoid and safe from experiencing shame and depression owing to the incompetency in reading being exposed to others. The studies mentioned above have helped in identifying that, not only does reading anxiety exists among the readers but it also has an important and considerable impact on the learner.

The feeling of apprehension and concern that arises within a learner who has to interpret a second language (L2) is referred to as foreign language reading anxiety. According to Horwitz et al. (1986: 215) "Reading anxiety is a specific type of anxiety from the more general types of foreign language anxiety that have been linked to oral performance." As a result, it could hold back and minimize the comprehension skills and acquisition of the second language. Maclntyrn (1995: 92) emphasizes that "when learner feel anxious during reading task completion, cognitive performance is diminished, performance suffers, leading to negative self-evaluations and more self-deprecating cognition which further impairs performance and so on.".

An in-depth study on reading anxiety helps us to understand some remarkable and interesting outcomes. A study by the academic researchers (Saito et al., 1999; Sellers, 2000; Shi \& Liu, 2006; Zhao, Guo \& Dynia, 2013) have helped us identify that the anxiety while reading a text in a foreign language is not linked with the presentation Horwitz et al. [3] in their study examined the concern while reading a foreign text. The students of Spanish, Russian and Japanese pursuing their first semester were studied for a time span of 30 hours. The study brings to light the fact that the feeling of nervousness and anxiety arising while reading a foreign text has a tremendous effect which is noticeable on the performance of the readers reading the text. Students possessing a comparatively lower anxiety level while reading are inclined to achieve and give enhanced results compared to those who experience high anxiety level.

Sellars (2000) carried out an analysis on 89 participants doing their third semester at the university level. The same study was conducted on intermediate level students who were doing their language course in Spanish at an institution of higher education and the results were studied to be similar. This study establishes that reading anxiety is an unavoidable and prominent characteristic in foreign language learning. Generally the scholars express the opinion of developing an uneasy feeling while reading a text in $\mathrm{L} 2$ compared to the activities related to reading. It was further established that learners who experience anxious feelings of a higher range while reading are more likely to remember minimal contents of the comprehension that they have read compared to the students who experience minimal anxiety. Taking into consideration all the studies, the anxiety caused while reading has an adverse effect on the performance.

Zuhana (2007) studied the connection between the reading apprehension and performance amongst the low proficiency ESL learners from local universities in Malaysia. The tools made use of for this study includes FLRAS, Cognitive Interference Questionnaire, and knowledgeable texts. The results of this study point out that reading anxiety is present in the midst of the tertiary learners in Malaysia. It was also found that when the anxiety caused by reading was high, the respondents had a lower level of comprehending the L2 academic manuscripts being given to them. 
Zhao (2008) based his learning on 125 students to whom Chinese was an unfamiliar language. This study was conducted in a public U.S university and the findings show that understanding of Chinese Texts was found to provoke apprehension to the students of non-western language as verbal communication did. The major basis of foreign language reading anxiety include unfamiliar scripts, unfamiliar topics and they had concerns about reading too. Zhao also finds a significant negative connection existing between foreign language reading anxiety and foreign language reading routine.

The study carried out by Tsai \& Li (2012) examined the potential connections between test anxiety, language reading anxiety and English reading skills using the different scales used in previous research in this area. $302 \mathrm{EFL}$ undergraduate college students enrolled in Learning English were tested with the Test Anxiety Scale, the Foreign Language Reading Anxiety Scale and a Measure of Learning Skills. The findings indicate that English reading skills have been found to be negative in relation with the anxiety generated by the exam and foreign language reading anxiety. The findings also showed that the test anxiety had a strong association with the anxiety of foreign language comprehension. The gap in reading skills between low- and high-anxiety students was not too important. Jafarigohar (2012) also identified similar findings on effective negative partnership existing between FLRA and reading comprehension. However, no traces of association were found to be existing between foreign language reading anxiety and the age factor. Comparing the anxiety level existing based on the gender differences, females were more nervous in comparison with male readers.

Zhao, Dynia, Guo (2013) summarized that students underwent a certain degree of reading anxiety while reading a foreign language. The anxiety level while reading a foreign level text is associated with the course level as seen in the study conducted with reading with by China students, however it was not related to the gender. The anxiety caused by reading a FL text was associated negatively with the reading performance of a FL between primary and middle level students. However, the students of elementary level II failed to experience the same reading anxiety.

Till the present day not many researches have been made in this field of study and researchers have failed to explain the relationship between foreign language reading anxiety and reading proficiency considering the group gender and field among the Saudi EFL learners. This study aims to measure the correlation between EFL reading anxiety and reading proficiency among learners of English language in the preparatory year at the University of Jeddah. The following research questions have been addressed to achieve the purpose of the study:

1. What is the participants' reading anxiety levels?

2. To what level would the FL interpret anxiety correlated with context variables such as gender and field group?

3. What is the relationship between reading anxiety and reading proficiency of the students at the University of Jeddah in preparatory years? 


\section{METHODOLOGY}

\section{Subjects}

The students from various disciplines in the University of Jeddah were identified for the study to be carried out. A total of 84 undergraduate respondents from the preparatory year pursuing their courses from the institution of languages at the University were selected for the study. Of the 84 participants, there were 43 male students (\% 51.2) and 41female students (\% 48.8). The English Program at the University of Jeddah aims at enhancing the academic and personal English skill set of the students and strengthen their English skills in the process. This would in turn enhance the Listening, Speaking, reading and Writing skills of the student, enabling them to enhance their proficiency in the language. Enhancing the skills would promote the growth of the linguistic and lexical competency in the students and develop their thinking skills, presentation skills and the subskills related to them. Books can be read for fulfilling different purposes. However in this course reading to serve the academic purposes and to appreciate the literary text is considered. The respondents were gathered and divided based on the groups they belonged to namely, the science and non-science group. Science group respondents are those studying science, for example in medicine and engineering, while non-science group refers to students taking courses in education and management.

\section{Instrumentation}

Two instrument measures have been used to explain, analyze and propose required results for the questions of the study. The instruments are the FL reading anxiety scale and the 5pointLikert-type scale

\section{A Reading Anxiety Questionnaire}

Saito et al. (1999) adapted the reading anxiety scale in foreign languages using the FL Reading Anxiety Scale (FLRAS). The questionnaire consists of two sections. The first part discusses the background information of the respondent and the second part deals with the second language reading anxiety scale. The FLRAS consists of 20 items measured using the 5-pointLikert-type scale ranging from 5 to 1.The scale of 5 representing -strongly agree and decreasing to the scale of to 1 representing the answer as strongly disagree. The negative wordings were reversed and thus the high ratings of the anxiety instrument were high. The study of scale reliability by Cronbach's $\alpha$ was .82 , suggesting that the scale was an accurate indicator of anxiety in reading.

\section{A Reading Test}

A reading comprehension section from the IELTS training exam was chosen to assess the study participants' reading abilities. After reading the passage the respondent was required to answer 20 questions in multiple-choice format. 


\section{Data collection}

The FLRAS was translated to the Arabic language, the language being the mother tongue of the participants. The questionnaire was distributed to the students during the regular class hours in the tenth week of the first semester of the year 2019, reflecting the fact that FL reading anxiety is situation-specific. This timing and measures was considered to avoid the possibility of challenges and difficulties arising while undergoing the analytical test by reading the comprehension passage. This methodology was adopted to assist the students and ensure that the respondents answered all the questions without any difficulties. The students were from varied levels of proficiencies and hence clarity and a good understanding of the question had to be ensured to prompt accurate responses. These measures taken were not applicable to highly proficient students as their language proficiency was sufficient for them to have a good understanding and answering of the reading comprehension. The study was conducted towards the end of the term as a part of their midterm examination. A major portion of their course had been completed and many had attained the outcome as expected from the course that they were pursuing.

An academic Reading comprehension paper of IELTS test was administered to the participants of the study. The students were guided to do the reading test within the stipulated time limit and answer the questionnaires that follow. The time limit for completing the reading comprehension test was 60 minutes which is the standard time allotted to the students attending an IELTS test. The respondents took an approximate of 15 minutes to answer the questionnaire. The score obtained by the participants' of this test were used to indicate the level of reading proficiency.

\section{RESULTS AND DISCUSSION}

The results of the tests show that the students felt strong reading anxiety. The range of scores is, as shown in Table 1. The minimum value in the scale is 1 and it ranges to a maximum of 5. $M=3.21$ is noted as the mean value for anxiety reading. The standard deviation is derived as $\mathrm{SD}=0.701$. The mean value that is derived in FLRAS indicates the anxiousness existing among the respondents to read an academic text in English, although their level of anxiety is mild. Contrasting to the general opinion, it is found that the common assumptions have been proved wrong as students with low proficiency were not vulnerable to experience an intense reading anxiety. The understanding is reliable and similar with the findings of (Oh's, 1990) and (Zin \& Rafik-Galea, 2010). It was reported in Oh's, 1990 study that the ESL learners in Korea underwent a similar a moderate anxiety level. The mean value of the Korean respondents was $M=2.39$. This was experienced by them while reading texts in the English language. In Zin \& Rafik-Galea 2010, students in Malaysia, while reading an English text reported a mild degree of anxiety. Their mean score valued to $M=3.43$. Sellers (2000) also recorded an average score of $M=2,63$, indicating that FL learners who answered their study had a reasonable level of anxiety. The mean score in this study is found to be comparatively high than the mean scores of the study conducted by (1990) and Sellers (2000), corresponding to the anxiety level. The results suggest that the respondents underwent an advanced level compared to the respondents in the experiments conducted by Oh's (1990) and that of Sellers' (2000). The reason for the variation in the scores obtained while calculating the mean can be attributed to the low efficiency of English learners of this study. 
Table 1: Descriptive statistic of the FLRAS

\begin{tabular}{|c|c|c|c|c|c|}
\hline & $\mathbf{N}$ & Min & Max & Mean & SD \\
\hline FLARS & 84 & 1 & 5 & 3.21 & 0.701 \\
\hline
\end{tabular}

Considering scores of the FLRAS in the scale, advanced studies was performed to identify the groups experiencing anxiety. In table 2 the students are classified into three levels based on their anxiety levels.

Table 2. The Anxiety Groups

\begin{tabular}{|c|c|c|}
\hline Anxiety group & Mean Score & Percentage \\
\hline Low anxiety & $1-2.40$ & $13 \%$ \\
\hline Mid anxiety & $2.41-3.70$ & $57 \%$ \\
\hline High anxiety & $3.71-5.00$ & $30 \%$ \\
\hline N. 84 & \\
\hline
\end{tabular}

According to Table 2, $13 \%$ of students are considered to be in the low-anxiety group, $57 \%$ in the moderate anxiety group and only $30 \%$ of them are considered to be in the high anxiety groups. The results show that students generally have moderate anxiety while reading a FL text. The outcomes of the FLRAS study relate to those of Sellers (2000). 65\% of the individuals were identified in the average anxiety group. The high anxiety group comprised of $18 \%$ of the respondents and the low anxiety group comprised of $17 \%$. Nevertheless, it's quite surprising, based on the same assumption that most participants are in the mild anxiety category. It was observed and concluded that the majority of the respondents experienced an advanced degree of anxiety while reading due to the lack of language knowledge in English.

The aspect of gender being considered as an angle of this study, an independent $t$-test was conducted to analyze the relationship between FLRAS and gender among the respondents. In table 3 , the results showed significance correlation between reading anxiety and their gender $t=(82)=-$ $3.179, \mathrm{p}<.00$ ), and field group (science \& art) $\mathrm{t}=(82)=2.902, \mathrm{p}<.00$ ). Regarding the differences between reading anxiety and their gender, the mean score of male students $(M=2.99)$ was lower than that of female respondents $(M=3.45)$. The results indicated that female students at the preparatory year were identified to be more anxious than their male counterparts. The results are similar with the study conducted by Jafarigohar (2012). The female learners are more anxious about the difficulties and hurdles that they face while reading a language difficulties than the male readers. The study identified women to be more anxious and concerned than men. As Bracken and Crain (1994) have affirmed in their studies, adolescence is a period when the interpersonal relations are found to be fluctuating to the core. At this phase of adolescence, the peer group is considered more important than the teachers and girls tend to depend more on their peers and communicating and socializing with the friends is prioritized. (Plancherel \& Bolognini, 1995) says that the female students have the fear of being laughed at by their peers. They level of anxiety increases while attending a test or being asked to answer in a teaching learning environment too. The anxiety level 
is found to be varying with regards to the discipline of study the reader belongs to .A student majoring in science discipline has varying anxiety levels compared to a student of the art discipline. The results revealed that science group students were more anxious than the arts students. The anxiety level mean score of the science group was found to be $(M=3.36)$ and the arts group was $(M$ $=2.91$ ). The notable variations in values between the two groups could be attributed to the motivation factor among the science group students to learn new subjects in the science field while concentrating on their core study subjects of medicine or engineering or other science related courses. On the other hand, the students of the arts group deal with subjects and topics that are related to their main subjects alone, which is generally opined to be easier than science. The results are inconsistent with other researches in the same field. (i.e. Daly, 1991; Rajab et al 2012) found that students of science are more likely to select the reading text, and the non-science community is not entirely unfamiliar with the genre.

Table 3: Independent Samples Test T-test Analysis for L2 Reading Anxiety according to Gender and Filed Group

\begin{tabular}{|c|c|c|c|c|c|c|c|}
\hline Variable & Category & $\mathbf{N}$ & Mean & SD & $\mathbf{t}$ & df & Sig. \\
\hline \multirow{2}{*}{ Gender } & Male & \multirow{2}{*}{84} & 2.99 & 0.769 & \multirow{2}{*}{-3.179} & \multirow{2}{*}{82} & \multirow{2}{*}{0.002} \\
\hline & Female & & 3.45 & 0.534 & & & \\
\hline \multirow{2}{*}{ Field group } & Science & \multirow{2}{*}{84} & 3.36 & 0.675 & \multirow{2}{*}{2.902} & \multirow{2}{*}{82} & \multirow{2}{*}{0.005} \\
\hline & Art & & 2.91 & 0.664 & & & \\
\hline
\end{tabular}

To determine the correlation between reading anxiety and reading proficiency, the researchers calculated the means and standard deviations as in table 4 for the reading proficiency test. As explained earlier, the reading comprehension text was used from an IELTS preparation test, and the test included 20 multiple-choice questions after the reading. The mean score of the reading proficiency was $(M=8.06)$ which indicated that the preparatory year students of the University of Jeddah had low proficiency of reading.

Table 4: Descriptive Statistic of the Reading Proficiency Test

\begin{tabular}{|c|c|c|c|c|c|}
\hline Category & N & Mean & SD & Min. & Max. \\
\hline Reading proficiency test & 84 & 8.06 & 3.283 & 2 & 17 \\
\hline
\end{tabular}

Following this a Pearson correlation test was performed to expose the correlation existing between the anxiety while reading and reading proficiency among the respondents. As shown in table 5 , the Pearson $r$ correlation between the reading anxiety and reading proficiency is negative $r=-.242^{*}, p<.02$ indicating that there is a direct correlation even though it is identified to be negative. The correlation coefficient demonstrates an inverted correlation that shows a decrease in the reading capacity as the anxiety level increases. The results of the study are in consistence with the previous studies conducted by (i.e. Young 2000; Sellars 2000; Zin \& Rafik-Galea 2010; Rajab et al. 2012). The studies conducted by them revealed that reading anxiety of the individuals affects the reading proficiency of students having a lower level of instruction. An acceptable argument suggested for the negative values existing between the FL reading anxiety and FL reading proficiency amongst the preparatory year students may be the lack of exposure to the writing system of English. 
They would also initially struggle to cope due to inadequate reading strategies to complete the reading tasks. Their reading proficiency which does not meet the required standards may add to their reading anxiety in the subsequent reading activities (Zhao, Dynia \& Guo 2013).

Table 5: Correlation between FLRAS and Reading Proficiency test

\begin{tabular}{|c|c|c|c|}
\hline \multicolumn{2}{|c|}{} & FLRAS & $\begin{array}{c}\text { Reading proficiency } \\
\text { test }\end{array}$ \\
\hline \multirow{3}{*}{ FLRAS } & Pearson Correlation & 1 & $-.242^{*}$ \\
\cline { 2 - 4 } & Sig. (2-tailed) & & .027 \\
\cline { 2 - 4 } & $\mathrm{N}$ & 84 & 84 \\
\hline \multirow{2}{*}{$\begin{array}{c}\text { Reading proficiency } \\
\text { test }\end{array}$} & Pearson Correlation & $-.242^{*}$ & 1 \\
\cline { 2 - 4 } & Sig. (2-tailed) & .027 & 84 \\
\cline { 2 - 4 } & $\mathrm{N}$ & 84 & \\
\hline *. Correlation is significant at the 0.05 level (2-tailed). & \multicolumn{2}{|c}{} \\
\hline
\end{tabular}

The inverse relationship that was observed in this research is coherent with the other research theories related to anxiety. Language anxiety research hypothesizes, particularly in an evaluative scenario (Sarason, Pierce, \& Sarason, 1996, ) suggests that the level of anxiety experienced by an individual has the capacity to have an impact on the level of performance of individuals experiencing anxiety. As an outcome, creating an atmosphere where the anxiety level is less would enable the readers to develop as more effective readers and produce fruitful results. This study would serve as a stepping stone to identify the reason for the anxiety prevailing in readers of FL text. Students may be motivated to overcome their FL reading anxieties by emphasizing on the anxiety sources and the discussions of this study.

\section{CONCLUSION AND IMPLICATIONS}

This study is an attempt to study the association between the reading anxiety and reading proficiency experienced by the readers. Academic reading texts were used for this study to be performed and the results obtained from the FLRAS pointed out that the majority of the year of training students with low proficiency at the University of Jeddah encountered mild anxiety while reading. Consequently, the assumption that while the feel of anxiety caused while reading was due to its existence as a practice was found to be contradicting. The results clearly suggest that similar effects can also be seen during reading exercises. However, that there may be no indication of anxiety reading. Contrary to oral activities, anxiety responses can be demonstrated by stammering, lack of vocabulary or expression. This is why Matsuda and Gobel (2001) call this kind of fear 'silent apprehension.'

The findings show that a greater percentage of students experience moderate anxiety on a scale of the reading anxiety ranging from moderate to high. The EFL learners with low proficiency in the language experience high levels of anxiety. The L2 or Foreign Language (FL) students usually considered as having a lower efficiency with respect to the language are expected to be more vulnerable to have a higher level of anxiety. The different criteria's that are prone to bring about a high anxiety level among the readers are, having a poor knowledge of the English language and reading academic texts. The experiments and evaluative methods adopted are not reliable enough 
in highlighting the anxiety which is high while reading corresponding to the students involved in this study. The level of anxiety among the second level respondents theorizes that learners of L2 have a low level of self perception and have maximum chances of experiencing high level of anxiety while performing different reading tasks in the language of different levels.

Most importantly, in the correlation analysis, Emphasis has to be laid on the negative relation existing between anxiety level and proficiency while reading supports the anxiety levels of the proficiency exhibited by the L2 readers. In this study we fail to provide substantiate results concerning the reading anxiety caused by poor performance and the data, it can be derived that demonstrate that, anxiety certainly plays a significant role in the reading performance level of the $\mathrm{L} 2$ readers.

The negative relation found in this study is identified to be consistent in most of the researches related to language anxiety research. Several researches suggest a mild negative association between language anxiety and the performance of L2 / FL students in the educational setting (see Horwitz, 2001; Maclntire and Gardner, 1991). This indicates that anxiety plays a major part in influencing L2 readers' comprehension. Together with some other studies on this field of reading anxiety (Matsuda and Gobel, 2001) this study provides further inputs to suggest the prevalence of anxiety while reading among the L2 and FL students. More significantly, it demonstrates that the reading output influences are negative. The findings are notable as this would enable the strengthening more researches in anxiety level among the readers and proves that anxiety does exist in a context related to language learning and reading skills in particular.

Female learners are more concerned about the language difficulties than males. Female readers prove to develop a higher level of anxiety compared to men. In co-education systems, the peer level anxiety is found to be prominent, students of both the gender study together. Another finding is related to the difference in anxiety levels arising as a result of the field groups (science \& art), and the results revealed that science group readers were more anxious than art group readers.

Pedagogically, because the ability of the $L 2$ readers to carry out their tasks effectively depends on the level of anxiety. The urgent necessity of $L 2$ teachers is to make sure that exercises or tasks related to reading in language classes do not create anxiety among the students. The FL instructors should identify the reading anxiety existing among the students and give extra attention towards the students facing these problems. Supportive instructional techniques should be adopted to encourage these students (Vogely, 1998; Young, 1991). Instructors in the classroom may organize and motivate more group reading activities and the instructor can guide the reading in the $\mathrm{FL}$ classrooms. These strategies have had positive effects on learners' participation in first-language classrooms in reading and improving their tutorial output (King, 2002; Tyner, 2009). As students enjoy reading in groups, insiders of the group provide word-recognizing help and can relate to other students in the difficulty of learning a foreign language. Discussing if the reading passage has a high level of difficulty or whether the topics are new to the students will reduce the anxiety of the class students. 


\section{REFERENCES}

Bracken, B. A., \& Crain, R. M. (1994). Children's and adolescents' interpersonal relations: age, race, and gender define normalcy? Journal of Psych educational Assessment, 12 (1), 14-32.

Capan, S. A., \& Karaca, M. (2013). A comparative study of listening anxiety and reading anxiety. Procedia-Social and Behavioral Sciences, 70, 1360-1373.

Cheng, Y. S. (2002). Factors associated with foreign language writing anxiety. Foreign Language Annuals, 35(5), 647-56

Daly, J. A. (1991). Understanding communication apprehension: An introduction for language educators. In E. K. Horwitz \& D. J. Young (Eds.), Language anxiety. From theory and research to classroom implications (pp. 3-13). Englewood Cliffs, NJ: Prentice Hall. (13) (PDF) Effects of Language Anxiety on Three Proficiency-Level Courses of Spanish as a Foreign Language.

Dias, A. F. (2020). Trans* escrevivências as a pedagogical power. Journal of Research and Knowledge Spreading, 1(1): 1-17.

Eysenck, M. W. (1985). Anxiety and cognitive-task performance. Personality and Individual Differences, 6, $579-586$.

Eysenck, M. W., \& Calvo, M. G. (1992). Anxiety and performance: The processing efficiency theory. Cognition and Emotion, 6, $409-434$.

Horwitz, E. K. (2001). Language anxiety and achievement. Annual Review of Applied Linguistics, 21, 112-126. http://dx.doi.org/10.1017/s0267190501000071

Horwitz, E. K., Horwitz, M. B., \& Cope, J. A. (1986). Foreign language classroom anxiety. The Modern Language Journal. 70, 2, 125-132

Heckler, V. et al. ECInvestigation with experimental practical activities in training geographically distant teachers. Journal of Research and Knowledge Spreading, 1(1): 1-15.

Jafarigohar, M. (2012). The Effect of Anxiety on Reading Comprehension Among Distance EFL Learners. International Education Studies, 5 (2), 159-174.

Jalongo, M. R., \& Hirsh, R. A. (2010). Understanding reading anxiety: New insights from neuroscience. Early Childhood Education Journal, 37(6), 431-435. http://dx.doi.org/10.1007/s10643-010-0381-5

King, C. (2002). "I like group reading because we can share ideas": The role of talk within the Literature Circle. Reading, 35, 32-36

Paraskeva, J. M. (2016). "Brutti, Sporchi \& Cattivi": Towards a Non-Abyssal Curriculum. Revista Tempos E Espaços Em Educação, 9(18), 75-90.

MacIntyre, P. D., \& Gardner, R. C. (1991). Language anxiety: Its relationship to other anxieties and to processing in native and second languages. Language Learning, 41, 513-534. http://dx.doi.org/10.1111/j.1467-1770.1991.tb00691.x 
MacIntyre, P.D. (1995) How Does Anxiety Affect Second Language Learning? A Reply to Sparks and Ganschow. The Modern Language Journal, 79, 90-99. https://doi.org/10.1111/j.1540-4781.1995.tb05418.x

Mohd. Zin, Zuhana (2007) The relationship between reading anxiety and academic reading performance among ESL learners. Masters thesis, Universiti Putra Malaysia.

Mohammadpur, B., \& Ghafournia, N. (2015). An elaboration on the effect of reading anxiety on reading achievement. English Language Teaching, 8(7), 206-215. DOI: 10.5539/elt.v8n7p206

Matsuda, S., Gobel, P., (2001). Quiet apprehension: reading and classroom anxieties. JALT Journal 23,227-247.

Oh, J. (1990). On the relationship between anxiety and reading in English as a foreign language among Korean university students in Korea. Unpublished Doctoral Dissertation. University of Texas, Austin.

Oxford, R. (1999). Anxiety and the Language Learner: New Insights. In J. Arnold (Ed.), Affect in Language Learning (pp. 58-67). Cambridge, UK: Cambridge University Press.

Plancherel, B., \& Bolognini, M. (1995). Coping and mental health in early adolescence. Journal of Adolescence, 18, 459-474.

Rajab, A., Zakaria, W. Z. W., Rahman, H. A., Hosni, A. D., \& Hassani, S. (2012). Reading anxiety among second language learners. Procedia-Social and Behavioral Sciences, 66, 362-369. https://doi.org/10.1016/j.sbspro.2012.11.279

Saito, Y., Horwitz, E. K., \& Garza, T. J. (1999). Foreign language reading anxiety. Modern Language Jour-nal,83, 202-218.

Sarason, I. G., Pierce, G. R., and Sarason, B. R. (1996). Domains of Cognitive Interference. In G. R. Pierce, B. R. Sarason, \& I. G. Sarason (Eds.), Cognitive interference: Theories, methods and findings (pp. 139-155). Hillsdale: Lawrence Erlbaum Associates.

Sellers, V. D. (2000). Anxiety and reading comprehension in Spanish as a foreign language. Foreign Language Annals,33, 512-521

Shi, Y. Z., \& Liu, Z. Q. (2006). Foreign language reading anxiety and its relationship to English achievement and gender. Journal of PLA University of Foreign Languages, 29, 59-65.

Tobias, S. (1979). Anxiety research in educational psychology. Journal of Educational Psychology, 71(5), 573-582. https://doi.org/10.1037/0022-0663.71.5.573

Tsai, Y.-C., \& Li, Y.-C. (2012). Test Anxiety and Foreign Language Reading Anxiety in a ReadingProficiency Test. Journal of Social Sciences, 8(1), 95-103. https://doi.org/10.3844/jssp.2012.95.103

Tyner, B. (2009).Small group reading instruction: A differentiated teaching model for beginning and struggling readers (3rd ed.). Newark, DE: International Reading Association.

Vogely, A. J. (1998). Listening comprehension anxiety: students' reported resources and solutions. Foreign Language Annals, 31 , 67-80. 
(13) (PDF) Foreign Language Reading Anxiety: Investigating English-Speaking University Students Learning Chinese as A Foreign Language in the United States.

Young, D. J. (1986). The relationship between anxiety and foreign language oral. Foreign Language Annals,19,439-445

Young, D. (2000). An investigation into the relationship between $L 2$ reading anxiety and L2 reading comprehension, and self-reported level of comprehension topic familiarity features of an L2 text and reading ability in the L1 and L2. Current Research on the Acquisition of Spanish (Eds.). Ron Leow \& Cristina Sanz. Summerville: Cascadilla Press.

Zin, Z. M., \& Rafik-Galea, S. (2010). Anxiety and academic reading performance among Malay ESL learners. Pan-Pacific Association of Applied Linguistic, 14(2), 41-58.

Zhao, A. (2008). Foreign language reading anxiety: Investigating English-speaking university students learning Chinese as a foreign language in the United States (Doctoral dissertation). Retrieved from ProQuest Dissertations and Theses database. (UMI No. 3374058)

Zhao, A., Guo, Y., \& Dynia, J. (2013). Foreign language reading anxiety: Chinese as a foreign language in the United States. The Modern Language Journal, 97, 764-778.

Zhou, J., 2017. Foreign language reading anxiety in a Chinese as a foreign language context. Reading in a Foreign Language, 29(1): 115-173.

\section{$\underline{\text { ABOUT THE AUTHOR }}$}

\section{Saleh Mohammad Ali Alqahtani}

Department of English Language and Translation, Faculty of Sciences and Arts, Khulais, University of Jeddah, Saudi Arabia.

Email: smalqahtani@uj.edu.sa

ORCID: https://orcid.org/0000-0002-6288-4871 